\title{
Consumer Acceptance of Wireless Finance
}

Citation for published version (APA):

Kleijnen, M. H. P., Wetzels, M. G. M., \& de Ruyter, J. C. (2004). Consumer Acceptance of Wireless Finance. Journal of Financial Services Marketing, 8(3), 206-217.

https://doi.org/10.1057/palgrave.fsm.4770120

Document status and date:

Published: 01/01/2004

DOI:

10.1057/palgrave.fsm. 4770120

Document Version:

Publisher's PDF, also known as Version of record

\section{Please check the document version of this publication:}

- A submitted manuscript is the version of the article upon submission and before peer-review. There can be important differences between the submitted version and the official published version of record.

People interested in the research are advised to contact the author for the final version of the publication, or visit the DOI to the publisher's website.

- The final author version and the galley proof are versions of the publication after peer review.

- The final published version features the final layout of the paper including the volume, issue and page numbers.

Link to publication

\footnotetext{
General rights rights.

- You may freely distribute the URL identifying the publication in the public portal. please follow below link for the End User Agreement:

www.umlib.nl/taverne-license

Take down policy

If you believe that this document breaches copyright please contact us at:

repository@maastrichtuniversity.nl

providing details and we will investigate your claim.
}

Copyright and moral rights for the publications made accessible in the public portal are retained by the authors and/or other copyright owners and it is a condition of accessing publications that users recognise and abide by the legal requirements associated with these

- Users may download and print one copy of any publication from the public portal for the purpose of private study or research.

- You may not further distribute the material or use it for any profit-making activity or commercial gain

If the publication is distributed under the terms of Article $25 \mathrm{fa}$ of the Dutch Copyright Act, indicated by the "Taverne" license above, 


\title{
Consumer acceptance of wireless finance
}

Received (in revised form): 22nd October, 2003

\section{Mirella Kleijnen}

is a PhD candidate with the Faculty of Economics and Business Administration, Maastricht University, the Netherlands. Her research focuses on the factors influencing consumer adoption of innovative services, and mobile services in particular. Her work has been published in Mobile Commerce: Technology, Theory, and Applications, International Journal of Service Industry Management and Total Quality Management.

\section{Martin Wetzels}

is a Full Professor of Marketing with the Faculty of Technology Management, Eindhoven University of Technology, the Netherlands. His main research interests are: new product development, electronic marketing, quality management, (online) marketing research, service marketing and management, relationship marketing and innovation and technology management. He has published more than 40 articles in international journals and has contributed more than 50 papers to conference proceedings.

\section{Ko de Ruyter}

is Professor of International Service Research at Maastricht University. He has published six books and articles in many journals including the Journal of Marketing, Journal of Economic Psychology, International Journal of Research in Marketing, Journal of Retailing, International Journal of Service Industry Management and Journal of Business Research.

\begin{abstract}
M-commerce has been heralded repeatedly as the new service frontier of the millennium. Present market reality, however, seems to be less optimistic. Therefore, the current study explores the factors contributing to the adoption of mobile services in a context of wireless finance. The technology acceptance model was used as a point of departure. For this study, perceived cost, system quality and social influence were added to the model, and the latter two displayed significant effects in the empirical research. Moderating effects of the variables age, computer skills, mobile technology readiness and social influence were investigated, all of which proved to be relevant in the context presented.
\end{abstract}

Keywords Wireless finance, technology adoption, partial least squares

\section{INTRODUCTION}

Wireless technology has been proclaimed as one of the most promising innovations of the last decade, creating tremendous business opportunities via the wireless infrastructure in terms of communications, transactions, purchasing, entertainment, trading, etc. Revenues of up to US\$15bn by the year 2006 have been predicted, while the numbers of users are forecasted to grow to 50 million in the USA alone. ${ }^{1}$ Based on these optimistic projections companies have made vast investments in wireless technology to serve these future users. It seems that this potential is mainly recognised on the supplier side, however, leaving many companies with enormous debts. ${ }^{2}$ Rather than pushing mobile technology through the market, marketers should investigate the underlying consumers' motivations that will lead to the adoption of wireless technology. Therefore, the current research will investigate the factors influencing new 
technology acceptance, thereby extending theory in the field of the technology acceptance model (TAM). ${ }^{3}$ There will be a comprehensive overview of relevant technology characteristics and consumer characteristics will also be investigated.

The results of this study will extend current knowledge on technology acceptance, and mobile technology in particular. The study will provide a deeper insight into what is needed in order for consumers to accept this new technology and will therefore allow for improved application design and strategy development.

\section{CONCEPTUAL FRAMEWORK}

The TAM model ${ }^{3}$ proposes that beliefs about usefulness and ease-of-use of a new system are essential elements in determining a user's attitude to using a technology. Attitude in turn positively affects consumers' usage intention. While the TAM model has been empirically verified, ${ }^{4-6}$ other researchers have recognised the need to adjust the model for different contexts. ${ }^{7,8}$ For the current research, perceived costs, perceived system quality and social influence have been incorporated as antecedents considering the relevance of these constructs for mobile service adoption. Additionally, several moderating variables have been included. In the following, an overview of the conceptual model is provided.

While perceived usefulness in the original TAM model strongly focuses on the extent to which a system adds to the consumer's job performance, ${ }^{5}$ the current context has a broader perspective. Mobile services can be accessed at any time, no matter where the consumer is, in a social as well as a business context. May ${ }^{9}$ refers to this phenomenon as the mobile lifestyle. Therefore, perceived usefulness is defined as how well consumers believe mobile services can be integrated into their daily activities. When this belief increases, the consumers' attitude to m-services will be more positive, and at the same time their intention to use these services will increase. Perceived ease of use is the extent to which a consumer believes a system is easy to learn or to use. ${ }^{5}$ For mobile services, several issues can contribute to the complexity; the hand-device might provide cumbersome navigation options; personal settings have to be implemented in order to use the services, etc. While perceived ease of use may have a direct positive effect on the attitude to mobile services, it also has a positive influence on the perceived usefulness. ${ }^{10}$ When consumers perceive the service to be complex and difficult to use, it is likely they will have difficulty in recognising the perceived usefulness of the new technology. ${ }^{11}$

Finally, next to perceived usefulness, it is suggested that attitude has a significant impact on behavioural intentions. Earlier studies on electronic channels have emphasised attitude to the channel itself, ${ }^{12}$ but when investigating usage intentions, attitude to using the channel is considered a more accurate predictor. ${ }^{13}$ This leads to the following hypotheses:

$\mathbf{H}_{1}$ : attitude to using mobile services has a direct, positive effect on the intention to use mobile services

$\mathbf{H}_{2}$ : perceived usefulness of mobile services has a direct, positive effect on the intention to use mobile services

$\mathbf{H}_{3}$ : perceived usefulness of mobile services has a direct, positive effect on the attitude to using mobile services

$\mathbf{H}_{\mathbf{4}}$ : Perceived ease of use has a direct, positive effect on the attitude to using mobile services

$\mathbf{H}_{5}$ : Perceived ease of use has a direct, positive effect on the perceived usefulness of mobile services

While the TAM model is valid and has 
gained increased acceptance over the years, recently, researchers have raised questions about the completeness of this model. Particularly when studying $\mathrm{m}$-commerce, additional factors contributing to attitude formation and usage intention have to be considered. ${ }^{14}$ The original TAM model was developed in an organisational context. As a consequence, the costs of using a particular technology as perceived by its users were not considered as a relevant variable since the actual user was not the same person as the one who was paying for the technology. When translating the model to a private context, however, cost becomes a relevant factor in the evaluation process. More particularly, recent studies have indicated that high prices are a major reason why consumers do not yet adopt mobile services. ${ }^{15}$ Therefore, it is proposed that perceived costs have a negative effect on the attitude to using mobile services.

$\mathbf{H}_{\mathbf{6}}$ : Perceived costs have a direct, negative effect on the attitude to using mobile services

Furthermore, perceived lack of quality is frequently considered to be a factor that makes consumers reluctant to use mobile services. ${ }^{16}$ The system quality, in particular, including factors such as speed of connection and download time seems to be of great concern to consumers. In this study, perceived system quality is defined as the degree to which individuals perceive that the connection between a mobile device and the internet is satisfying, in terms of transfer speed and reliability. The authors contend that when the consumer perceives system quality to be high, his or her attitude to mobile services will become more positive.

$\mathbf{H}_{\mathbf{7}}$ : Perceived system quality has a direct, positive effect on the attitude to using mobile services
Additionally, several studies indicate the need to include social influence as a motivation for consumers actually to use new technologies. This social influence is executed by relevant others in the consumer's environment. Studies in the field of e-commerce and e-mail ${ }^{7,17}$ have found that social influence has a direct effect on usage. While the investigation of these direct effects is relevant, other studies have suggested the need to investigate moderating effects, as they are less obvious. ${ }^{13}$ Taking into account the findings of a recent study in the field of self-service technology, ${ }^{13}$ this study will also investigate the moderating effect of social influence on the relationship between attitude to using mobile services and usage intention. Similar to the selfservice technology study it is suggested that situational factors can interfere with the effect of attitude on intention. In other words, social influence will attenuate the relationship between attitude and intention.

$\mathbf{H}_{\mathbf{8} \mathbf{a}}$ : Social influence has a direct, positive effect on the intention to use mobile services

$\mathbf{H}_{\mathbf{8 b}}$ : As social influence is greater, the relationship between attitude and intention to use mobile services will be attenuated

Several studies have devoted attention to individual differences that play a role in consumer adoption. ${ }^{18}$ This study considers three factors that moderate the relationship between attitude and its antecedents: age, computer skills and mobile technology readiness. Although traditional adoption research claims no significant differences between early and late adopters, ${ }^{19}$ mobile services seem to be more appealing to young generations, ${ }^{20}$ judging from the massive use of mobile telephony by this consumer group and interest in services related to mobile phones. ${ }^{21}$ Therefore, it is 
expected that the relationship between the attitude and its antecedents is moderated by the consumer's age.

$\mathbf{H}_{\mathbf{9}}$ : As consumers become older,

- the positive relationship between perceived usefulness and attitude is strengthened

- the positive relationship between perceived ease of use and attitude is strengthened

- the negative relationship between perceived costs and attitude is strengthened

- the positive relationship between perceived system quality and attitude is strengthened

Additionally, prior experience with similar products or services might influence the adoption of an innovation. ${ }^{22,23}$ As stated by Citrin et al., ${ }^{24}$ this is a logical outcome as heavy users of a product, service or system have acquired the ability or knowledge structure to predict outcomes for a closely related product/service/ system. Despite several differences, similarities between the employment of computers for economic purposes and $\mathrm{m}$ commerce can be detected. For example, mobile banking provides services similar to e-banking, ie making transactions, retrieving account information, etc. Consumers who have more knowledge about similar technologies will be most likely to experience less difficulty with mobile services and to be less worried about problems related to the system quality. Therefore, it is argued that computer skills moderate the relationship between perceived system quality and attitude, as well as the relationship between ease of use and attitude.

$\mathbf{H}_{\mathbf{1 0}}$ : As consumers become more experienced,

- the positive relationship between perceived ease of use and attitude is attenuated
- the positive relationship between perceived system quality and attitude is attenuated

Furthermore, research has recognised that variation arising from personality traits is of greater interest than demographic or psychographic factors because such variation is at the heart of consumer attitude formation and behavioural intention. ${ }^{13}$ Therefore, the authors also include a mobile technology readiness index in the model. The technology-readiness construct refers to 'people's propensity to embrace and use new technologies for accomplishing goals in home life and at work' ${ }^{25}$ Previous research attempted to include variables that might provide a signal for such readiness, such as anxiety ${ }^{26}$ or self-efficacy. ${ }^{13}$ The technology readiness index, ${ }^{25}$ however, provides a comprehensive construct of the actual phenomenon measuring 'an overall state of mind resulting from a gestalt of mental enablers and inhibitors that collectively determine a person's predisposition to use new technologies'. The index consists of four dimensions: innovativeness, optimism, discomfort and insecurity. Again, the authors include this construct as a moderating variable in the model, where mobile technology readiness moderates the relationship between attitude and its antecedents. For example, consumers with a high mobile technology readiness will probably be less concerned with ease of use, as they are eager to use the new technology regardless of its ease of use. Additionally, in line with Dabolkar and Bagozzi, ${ }^{13}$ it is expected that consumers who are more technology ready are likely to be more eager to use new technology-based services and will rely less on their existing attitude in their decision to use mobile services.

$\mathbf{H}_{\mathbf{1 1}}$ : As consumers express higher mobile technology readiness

- the positive relationship between 


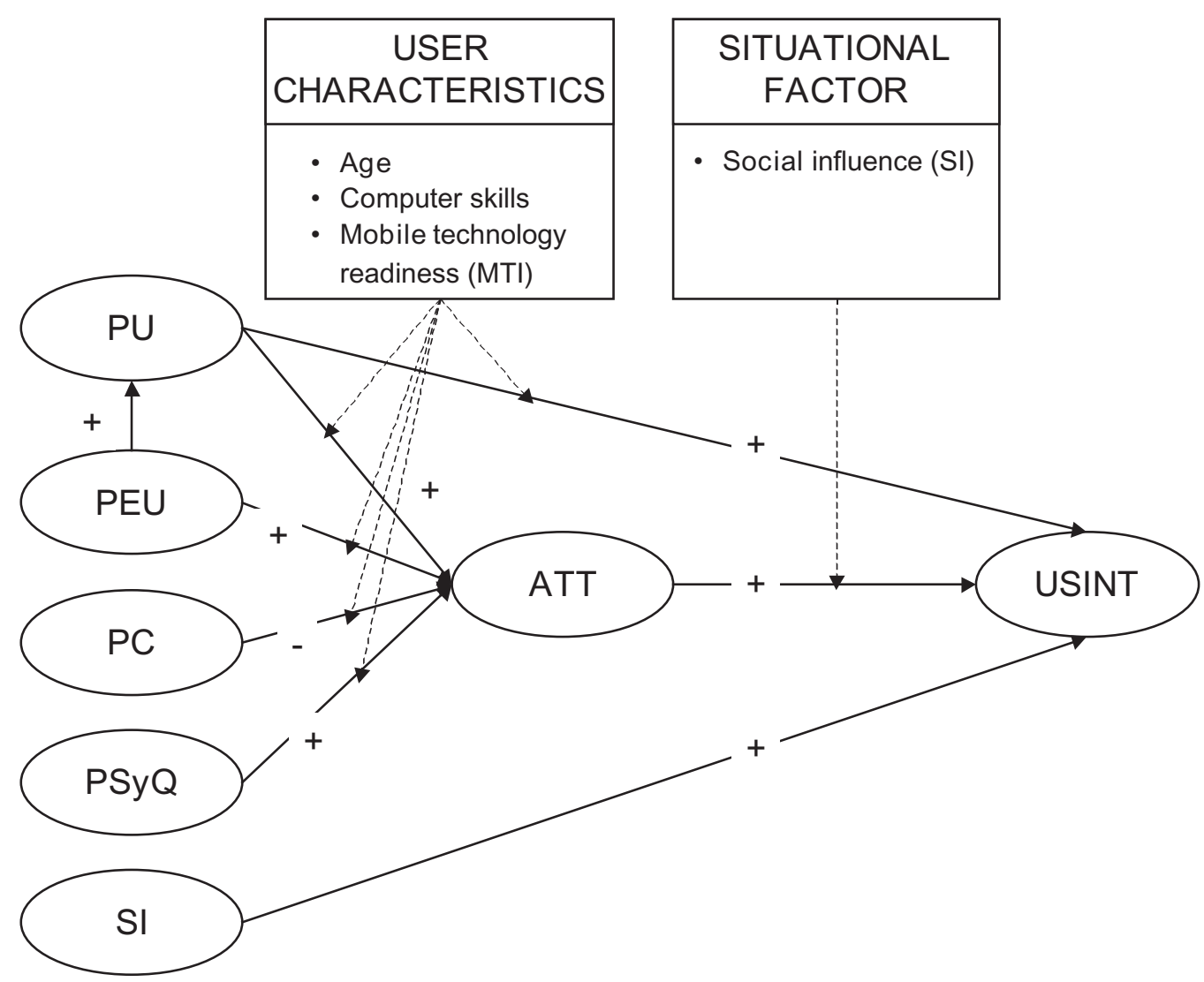

Figure 1 Relationships in conceptual model ${ }^{\mathrm{a}}$

Note: $\mathrm{PU}=$ Perceived usefulness, $\mathrm{PEU}=$ Perceived ease of use, $\mathrm{PC}=$ Perceived costs, $\mathrm{Psy} \mathrm{Q}=$ Perceived systems quality, $\mathrm{SI}=$ Social influence, $\mathrm{ATT}=$ Attitude, USINT = Usage intentions

perceived usefulness and attitude is attenuated

- the positive relationship between perceived ease of use and attitude is attenuated

- the negative relationship between perceived costs and attitude is attenuated

- the positive relationship between perceived system quality and attitude is attenuated

- the positive relationship between attitude and intention to use is attenuated

The conceptual framework is graphically depicted in Figure 1.

\section{EMPIRICAL RESEARCH}

The research was conducted by means of a questionnaire. Multi-item scales were employed based on previously published scales with favourable psychometric properties $^{5,7,25}$ and adapted for the current context (see Table 1). In total, 203 respondents were approached to participate via a mall intercept. Out of these 203, 49 per cent refused to participate or were not able to answer the questionnaire due to a lack of experience concerning mobile financial services. A final sample of 105 respondents was collected, all of which possessed a mobile phone with WAP technology and were screened for actual 
Table 1 Sample items questionnaire

\begin{tabular}{|c|c|c|}
\hline Construct & $\begin{array}{l}\text { Number of } \\
\text { items }\end{array}$ & Sample item \\
\hline Perceived usefulness & 7 & WAP technology enables me a faster accomplishment of tasks \\
\hline Perceived ease of use & 4 & $\begin{array}{l}\text { I often find it cumbersome to use WAP applications } \\
\text { (reversed item) }\end{array}$ \\
\hline Perceived system quality & 3 & $\begin{array}{l}\text { The speed of connection between WAP phones and } \\
\text { the internet is satisfying }\end{array}$ \\
\hline Attitude & 3 & In general, I have a positive opinion about WAP services \\
\hline Intention to use & 2 & $\begin{array}{l}\text { Expressed in terms of minutes online via mobile technology (on } \\
\text { a weekly basis) }\end{array}$ \\
\hline Social influence & 3 & Your friends and relatives encourage you to use WAP services \\
\hline
\end{tabular}

use of wireless application protocol (WAP) for wireless finance purposes. These criteria were employed to ensure good quality responses. Only respondents who had used wireless financial services at least once were incorporated in the sample, which does not necessarily imply that they have adopted the service, rather that they are knowledgeable regarding the specific questions concerning, for instance, ease of use and perceived system quality. The resulting sample can be described as follows: gender (male 79 per cent, female 21 per cent), and age ( $<25$ years 59 per cent, $>25$ years 41 per cent).

\section{FINDINGS}

The partial least squares (PLS) approach was used to estimate both the measurement and the structural parameters in the structural equation model. ${ }^{27-31}$ PLS does not require multivariate normal data, places minimum requirements on measurement levels and is more suitable for small samples. ${ }^{28,31}$ In the study reflective indicators were specified for all the constructs. The measurement model was tested with no relationships specified among the constructs, using PLS analysis as implemented in PLS-Graph Version 3.0. ${ }^{32}$
The reliability, convergent validity and discriminant validity were examined for the measurement instruments used in the study. Reliability was assessed using composite scale reliability ${ }^{28,33,34}$ and average variance extracted. ${ }^{28,33}$ Composite scale reliability ranged between 0.77 and 0.95 exceeding the cut-off value of $0.7 .^{35}$ Average variance extracted ranged between 0.54 and 0.87 exceeding the 0.5 cut-off value. ${ }^{33}$

Convergent validity can be evaluated by inspecting the factor loadings of the measures on their respective constructs. Discriminant validity can be assessed by examining the cross-factor loadings of the measures. ${ }^{27,28,36}$ The measures should not load higher on another construct than it is intended to measure. Additionally, a construct should share more variance with measures than it shares with other constructs in the model. ${ }^{27,28,36}$ Consequently, the square root of the average variance extracted should exceed the intercorrelations of the construct with the other constructs in the model. In the study all the measures showed factor loadings exceeding 0.6 and no factor crossloadings exceeded the factor loadings on the respective constructs. Moreover, none of the intercorrelations of the constructs 
employed in the study exceeded the square root of the average variance extracted for the constructs.

\section{MEDIATING EFFECTS}

PLS-Graphs Version 3.0 32 was used to estimate the parameters in the structural model in order to test for the relationships specified in the conceptual framework. To test the effects and the statistical significance of the parameters in the structural model a bootstrapping procedure was used with 500 resamples. ${ }^{28,32,37}$ The results indicate that except for the direct effect of perceived usefulness on intention $\left(\mathbf{H}_{\mathbf{2}}\right)$ and the effect of perceived costs on attitude $\left(\mathbf{H}_{\mathbf{6}}\right)$, all the hypotheses for the core model can be confirmed. Employing a significance level of 5 per cent, the results revealed a positive and significant effect of PEU on PU $(\beta=0.526)$ resulting in a $R^{2}$ for PU of 0.28 . Moreover, ATT is positively and significantly affected by $\mathrm{PU}(\beta=0.556)$ and PsyQ $(\beta=0.271)$ resulting in a $R^{2}$ for ATT of 0.52 . Finally, USINT is positively and significantly influenced by SI $(\beta=0.170)$ and ATT $(\beta=0.271)$ resulting in a $R^{2}$ for USINT of 0.19 . The results are shown in Figure 2.

\section{MODERATING EFFECTS}

In order to test for the moderator effects specified in the conceptual model a method was used analogous to moderated regression analysis. ${ }^{36,38}$ To test for the significant effects of the moderator variables two groups were established for

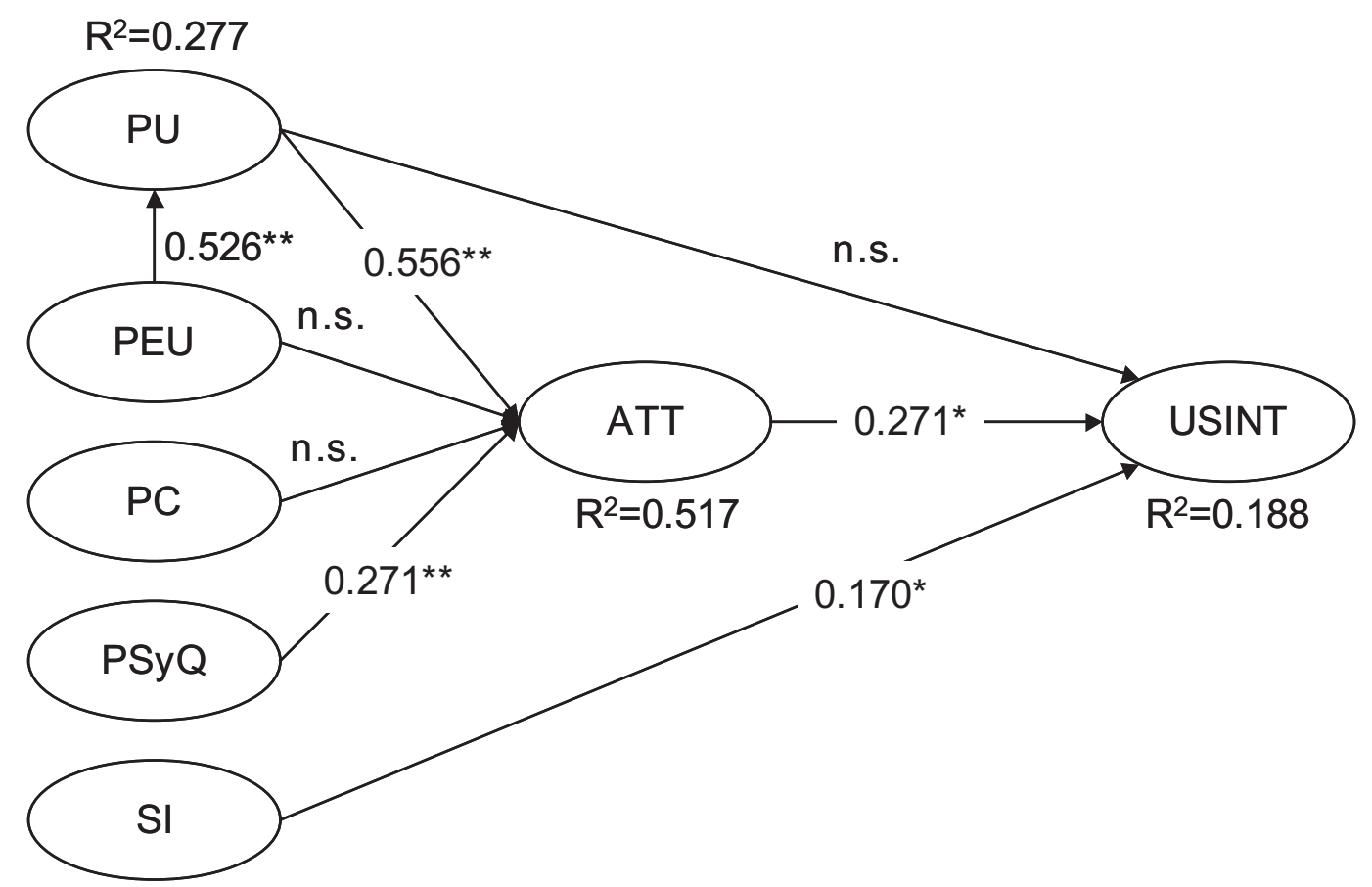

Figure 2 Results Mediating Model

Note: $\mathrm{PU}=$ Perceived usefulness, $\mathrm{PEU}=$ Perceived ease of use, $\mathrm{PC}=$ Perceived costs, $\mathrm{Psy} \mathrm{Q}=$ Perceived systems quality, $\mathrm{SI}=$ Social influence, $\mathrm{ATT}=$ Attitude, $\mathrm{USINT}=$ Usage intentions

* significant at $a=0.05$

${ }^{* *}$ significant at $a=0.01$ 
Table 2 Moderating effects

\begin{tabular}{|c|c|c|c|c|c|c|c|}
\hline \multirow{2}{*}{$\begin{array}{l}\text { Moderator } \\
\text { Age }\end{array}$} & \multirow{2}{*}{$\begin{array}{l}\begin{array}{l}\text { Moderated } \\
\text { relationship }\end{array} \\
\mathrm{PU} \rightarrow \mathrm{ATT} \\
\mathrm{PEU} \rightarrow \mathrm{ATT}\end{array}$} & \multirow{2}{*}{$\begin{array}{l}\begin{array}{l}\text { Expected } \\
\text { direction }\end{array} \\
\text { Strengthened } \\
\text { Strengthened }\end{array}$} & \multicolumn{3}{|c|}{ Beta (low vs. high) ${ }^{b}$} & \multirow{2}{*}{$\begin{array}{l}t \\
-8.97\end{array}$} & \multirow{2}{*}{$\begin{array}{l}p \\
<0.001\end{array}$} \\
\hline & & & $\begin{array}{l}\beta=0.404 \\
\text { n.s. }\end{array}$ & vs. & $\beta=0.651$ & & \\
\hline & $\mathrm{PC} \rightarrow \mathrm{ATT}$ & Strengthened & $\beta=0.021$ & vs. & $\beta=-0.341$ & 11.68 & $<0.001$ \\
\hline & PSyQ $\rightarrow$ ATT & Strengthened & $\beta=0.445$ & vs. & $\beta=0.110^{\mathrm{a}}$ & 10.63 & $<0.001$ \\
\hline \multirow[t]{2}{*}{ Computer skills } & $\mathrm{PEU} \rightarrow \mathrm{ATT}$ & Attenuated & n.s. & & & & \\
\hline & $\mathrm{PSyQ} \rightarrow \mathrm{ATT}$ & Attenuated & $\beta=0.350$ & vs. & $\beta=0.229$ & 4.08 & $<0.001$ \\
\hline \multirow[t]{4}{*}{$\begin{array}{l}\text { Mobile technology } \\
\text { readiness }\end{array}$} & $\begin{array}{l}\mathrm{PU} \rightarrow \mathrm{ATT} \\
\mathrm{PEU} \rightarrow \mathrm{ATT}\end{array}$ & $\begin{array}{l}\text { Attenuated } \\
\text { Attenuated }\end{array}$ & $\begin{array}{l}\beta=0.407 \\
\text { n.s. }\end{array}$ & vs. & $\beta=0.666^{\mathrm{a}}$ & -9.23 & $<0.001$ \\
\hline & $\mathrm{PC} \rightarrow \mathrm{ATT}$ & Attenuated & $\beta=0.098$ & vs. & $\beta=-0.265^{\mathrm{a}}$ & 11.50 & $<0.001$ \\
\hline & PSyQ $\rightarrow$ ATT & Attenuated & $\beta=0.533$ & vs. & $\beta=0.151$ & 12.42 & $<0.001$ \\
\hline & $\mathrm{PU} \rightarrow \mathrm{INT}$ & Attenuated & $\beta=0.238$ & vs. & $\beta=0.119$ & 2.84 & 0.003 \\
\hline Social influence & ATT $\rightarrow$ INT & Attenuated & $\beta=0.389$ & vs. & $\beta=0.152$ & 5.78 & $<0.001$ \\
\hline
\end{tabular}

${ }^{a}$ Relationship is significant, but in contradiction to the hypothesis

${ }^{b}$ The moderating effect was investigated based on a median split. Interpretation of the beta therefore is similar to the interpretation of the beta of the core model. For example: the beta measuring the effect of perceived usefulness (PU) on attitude (ATT) for young consumers is 0.404 , while the beta measuring the same effect for older consumers is 0.651 . The beta of the older consumers is significantly higher then the beta of the younger consumers $(t=-8.97, p<0.001)$, therefore hypothesis H9a is supported

each moderator on the basis of a median split. PLS was subsequently used to obtain parameter estimates and bootstrapping to provide the standard errors of the estimates and the accompanying $t$ statistics. The path coefficients for the two groups can be tested for significance using an independent samples $t$ test. $^{36,38,39} \mathrm{~A}$ conservative $a$-value of 0.01 was used for the significance level. The results are reported in Table 2.

Many of the hypotheses were confirmed, however there are some results that were not consistent with expectations. The results indicate that only three of the hypothesised moderating effects are not significant. There is no significant difference in the effect that PEU has on ATT between younger and older consumers $\left(\mathbf{H}_{\mathbf{9 b}}\right)$; this might be related to the particular service setting used for the study. Wireless finance can be a very timesensitive service; trading stocks for example demands fast moves that should not be complicated by difficult actions or procedures. Even though younger consumers are believed to be more positive about mobile services in general, they might require the same ease of use as older consumers in the case of timesensitive services. The same line of reasoning can be applied to the moderating effect of computer skills $\left(\mathbf{H}_{\mathbf{1 0 a}}\right)$ and mobile technology readiness $\left(\mathbf{H}_{\mathbf{1 1 b}}\right)$ on the relationship between PEU and ATT, where also no significant results were found.

Additionally, some moderating effects were contrary to expectations. In the case of age $\left(\mathbf{H}_{\mathbf{9 d}}\right)$, the effect of PSyQ on ATT is not strengthened but attenuated for older consumers. An explanation for this might be that older consumers are less knowledgeable about mobile commerce, and therefore do not know what they can reasonably expect of the system quality. Therefore, they might be less critical and consequently put less emphasis on this factor. Also, the moderating effect of mobile technology readiness on the relationship between PU and ATT is strengthened instead of attenuated, as was expected $\left(\mathbf{H}_{\mathbf{1 1} \mathbf{a}}\right)$. Moreover, the moderating effect of mobile technology readiness on the relationship between $\mathrm{PC}$ and ATT is strengthened instead of attenuated $\left(\mathbf{H}_{\mathbf{1 1}} \mathbf{c}\right)$. The reason why these effects might occur is that consumers who 
Table 3 Overview results

\begin{tabular}{|c|c|c|}
\hline No. & Hypothesis & Result \\
\hline $\mathrm{H}_{1}$ & attitude $\rightarrow$ intention to use & Supported \\
\hline $\mathbf{H}_{2}$ & perceived usefulness $\rightarrow$ intention to use & Not significant \\
\hline $\mathbf{H}_{3}$ & perceived usefulness $\rightarrow$ attitude & Supported \\
\hline $\mathbf{H}_{4}$ & perceived ease of use $\rightarrow$ attitude & Not significant \\
\hline $\mathbf{H}_{5}$ & perceived ease of use $\rightarrow$ perceived usefulness & Supported \\
\hline $\mathbf{H}_{6}$ & perceived costs $\rightarrow$ attitude & Not significant \\
\hline $\mathbf{H}_{7}$ & perceived system quality $\rightarrow$ attitude & Supported \\
\hline $\mathbf{H}_{\mathbf{8 a}}$ & social influence $\rightarrow$ intention to use & Supported \\
\hline $\mathbf{H}_{\mathbf{8 b}}$ & social influence attenuates attitude $\rightarrow$ intention to use & Supported \\
\hline $\mathbf{H}_{9 \mathbf{a}}$ & Age strengthens perceived usefulness $\rightarrow$ attitude & Supported \\
\hline$H_{9 b}$ & Age strengthens perceived ease of use $\rightarrow$ attitude & Not significant \\
\hline $\mathrm{H}_{9 \mathrm{c}}$ & Age strengthens perceived costs $\rightarrow$ attitude & Supported \\
\hline$H_{9 d}$ & Age strengthens perceived system quality $\rightarrow$ attitude & Significant, but opposite direction \\
\hline $\mathrm{H}_{10 \mathrm{a}}$ & Computer skills attenuate perceived ease of use $\rightarrow$ attitude & Not significant \\
\hline $\mathrm{H}_{10 \mathrm{~b}}$ & $\begin{array}{l}\text { Computer skills attenuate perceived system quality } \rightarrow \text { attitude } \\
\text { is attenuated }\end{array}$ & Supported \\
\hline $\mathrm{H}_{11 \mathrm{a}}$ & $\begin{array}{l}\text { mobile technology readiness attenuates perceived usefulness } \\
\rightarrow \text { attitude }\end{array}$ & Significant, but opposite direction \\
\hline$H_{11 b}$ & $\begin{array}{l}\text { mobile technology readiness attenuates perceived ease of } \\
\text { use } \rightarrow \text { attitude }\end{array}$ & Not significant \\
\hline$H_{11 c}$ & $\begin{array}{l}\text { mobile technology readiness attenuates perceived costs } \\
\rightarrow \text { attitude }\end{array}$ & Significant, but opposite direction \\
\hline$H_{11 d}$ & $\begin{array}{l}\text { mobile technology readiness attenuates perceived system } \\
\text { quality } \rightarrow \text { attitude }\end{array}$ & Supported \\
\hline $\mathrm{H}_{11 \mathrm{e}}$ & $\begin{array}{l}\text { mobile technology readiness attenuates attitude } \rightarrow \text { intention } \\
\text { to use }\end{array}$ & Supported \\
\hline
\end{tabular}

are more technology ready might also be more aware of technology in general: they are aware of possible alternatives and are capable of critically evaluating whether or not these new services offer true added value, in general and in relation to price. A complete overview of the results can been found in Table 3 .

\section{CONCLUSION AND SUGGESTIONS FOR FURTHER RESEARCH}

This study was developed to create a deeper understanding of consumer motivations concerning mobile services. Wireless finance was chosen as a research context. The results indicate that almost all the hypothesised relationships in the core model were confirmed. Although the relationships between perceived usefulness on intention and the effect of perceived costs on attitude were not significant in the core model, these relationships do become important when including the moderating effects. Furthermore, several moderating effects were found. Although not all hypotheses were confirmed, the results suggest strong support for the inclusion of these variables in the model. Moreover, some striking results concerning the moderating variables were found, which indicate further research directions. For example, contrary to the expectations, the effect of perceived usefulness has a stronger positive effect on usage intentions for younger consumers 
than older consumers. This might imply that young consumers are more extrinsically motivated than older consumers, ie they are more concerned with the outcome than the process. ${ }^{40}$ Therefore, further research might investigate the added value of mobile services. While this added value might pertain to functional values, recent research indicates that more hedonic or experiential aspects should not be overlooked. ${ }^{41}$ In line with this, the authors suggest the inclusion of variables such as perceived enjoyment. ${ }^{13}$ Although this factor was omitted in the current study as it seems less relevant for functional services such as mobile banking, the authors expect significant relevance for more experiential services such as mobile gaming. Furthermore, the moderating effect of mobile technology readiness was not always as expected. An underlying factor that might be related to these results is the expertise of such customers. The reason that these consumers might evaluate more critically might not only be because of their interest, but also because they have the ability to be more critical. Previous research has indicated that expertise is related to, for instance, innovativeness ${ }^{42}$ and might therefore be considered when investigating the model further.

Additionally, the results of the core model have indicated a significant impact of attitude and social influence on the intention to use wireless services. The variance explained by those two variables is relatively low, however, suggesting that there are other variables that might have an impact on consumers' usage intentions. While this is not an uncommon finding in technology acceptance studies, ${ }^{4}$ further research is necessary to uncover variables that have a direct impact on intentions to use wireless services. Finally, the research was based on the assumption that antecedents of user intentions are similar for adopters and non-adopters.
Motivations for not adopting mobile services might illustrate different patterns, however, and may even include different variables.

Next to these omitted variables, there are some limitations to the research that lead to additional suggestions for further research. A potential limitation of the study is the possibility of common method variance in the observed relationships. This problem cannot be managed statistically; it is inherent in this particular design and can be solved by measuring outcome and predictor variables independently, eg measuring actual use of mobile services by screening mobile transaction records. Implementing such measures can be extremely complex, however, from a managerial point of view. Furthermore, the authors suggest a cross-validation of their results in terms of different types of service. While the current research has focused on wireless finance, future research should also investigate other mobile services, such as mobile entertainment. Finally, the study has taken a crosssectional perspective, which leads to a snapshot presentation of the current reality. Further validation of the results using longitudinal studies would add to the value of the conceptual model.

\section{MANAGERIAL IMPLICATIONS}

Several interesting managerial implications can be derived. First of all, perceived costs seem to play a less important role than was expected. An explanation for this finding might be that costs are of minor importance as long as the mobile service delivers high quality content. According to Advani and Choudhury, ${ }^{43}$ companies should focus on providing $\mathrm{m}$-services that deliver unique, value-adding content rather than existing services via a different channel. Additionally, the significant moderating effects indicate that a segmentation approach might be very 
effective. In particular, age might be a very attractive criterion on which to segment considering that most companies nowadays have demographic information about their customers. The effects of computer skills and mobile technology readiness should not be overlooked, however, indicating that companies should extend their databases to include more consumer characteristics that go beyond sociodemographic profiling. Finally, social influence offers challenging opportunities to mobile services providers. The results suggest that advertising should focus more on situational contexts, rather than on functional aspects of mobile services. Moreover, positive worth of mouth seems more important than ever, bearing in mind that friends or colleagues might play a key role in persuading consumers to use mobile services.

\section{References}

1 Reuters (2001) 'The yankee group publishes U.S. mobile commerce forecast'. Press release, retrieved 2nd June, 2003: http://www.about.reuters.com/ newsreleases/art_31-10-2001_id765.asp.

2 The Economist (2000) 'The wireless gamble', The Economist, 12th October, retrieved 24th April, 2001: http://www.economist.com.

3 Davis, F. D. (1986) 'A technology acceptance model for empirically testing new end-user information systems: Theory and results' [Doctoral dissertation]. Massachusetts Institute of Technology, Boston, MA.

4 Lederer, A. L., Maupin, D. J., Sena, M. P. and Zhuang, Y. (2000) 'The technology acceptance model and the world wide web', Decision Support Systems, Vol. 29, No. 3, pp. 269-282.

5 Davis, F. D., Bagozzi, R. P. and Warshaw, P. R. (1989) 'User acceptance of computer technology: A comparison of two theoretical models', Management Science, Vol. 35, No. 6, pp. 982-1003.

6 Adams, D., Nelson, R. and Todd, P. (1992) 'Perceived usefulness, ease of use, and usage of information technology: A replication', MIS Quarterly, Vol. 16, No. 2, pp. 227-247.

7 Karahanna, E. and Limayem, M. (2000) 'E-mail and vmail usage: Generalising across technologies'. Journal of Organizational Computing and Electronic Commerce, Vol. 10, No. 1, pp. 49-66.

8 Hong, W., Thong, J. Y. L., Wong, W.-M. and Tam, K.-Y. (2001-2002) 'Determinants of user acceptance of digital libraries: An empirical examination of individual differences and system characteristics', Journal of
Management Information Systems, Vol. 18, No. 3, pp. 97-124.

9 May, P. (2001) 'Mobile commerce - breakthroughs in application development: Opportunities, applications and technologies of wireless business', Cambridge University Press, Cambridge, UK.

10 Davis, F. D. (1989) 'Perceived usefulness, perceived ease of use, and usage of information technology: A replication', MIS Quarterly, Vol. 16, No. 2, pp. 319-339.

11 Davis, S. and Wiedenbeck, S. (2001) 'The mediating effects of intrinsic motivation, ease of use and usefulness perceptions on performance in first-time and subsequent computer users', Interacting with Computers, Vol. 13, No. 5, pp. 549-580.

12 Bobitt, L. M. and Dabholkar, P. A. (2001) 'Integrating attitudinal theories to understand and predict use of technology-based self-service: The internet as an illustration', International Journal of Service Industry Management, Vol. 12, No. 5, pp. 423-451.

13 Dabholkar, P. A. and Bagozzi, R. P. (2002) 'An attitudinal model of technology-based self-service: Moderating effects of consumer traits and situational factors', Journal of the Academy of Marketing Science, Vol. 30, No. 3, pp. 184-201.

14 Chou, Y., Lee, C. and Chung, J. (in press) 'Understanding m-commerce payment systems through the analytic hierarchy process'. Journal of Business Research, Vol. forthcoming.

15 MobiCom Consortium (2001) 'European mobile commerce survey 2001', retrieved 10th November, 2002: http://www.mobiforum.org.

16 Stellin, S. (2001) 'Wireless customers seek better quality of service', The New York Times, 20th August.

17 Fang, K. (1998) 'An analysis of electronic-mail usage', Computer in Human Behavior, Vol. 14, No. 2, pp. 349374.

18 Agarwal, R. and Prasad, J. (1998) 'Are individual differences germane to the acceptance of new information technologies?' Decision Sciences, Vol. 30, No. 2, pp. 361-391.

19 Rogers, E. M. and Shoemaker, F. F. (1971) 'Communication of innovations: A cross-cultural approach', The Free Press, New York.

20 Noakes, R. (2002) 'Driving mobile commerce in the US: Who is leading whom?' Proceedings Silicon Valley World Internet Center, Think Tank Session 29th August, 2001, retrieved 7th November, 2002: http://www.worldinternetcenter.com.

21 Sawall, A. (2000) 'Mobile phone boom amongst teens is apparent on the internet', Internet News, 4th December, retrieved 7th November, 2002: www.internetnews.com/bus-news/article.php/525101.

22 Carlson, J. R. and Zmud, R. W. (1999) 'Channel expansion theory and the experimental nature of media richness perceptions', Academy of Management Journal, Vol. 42, No. 2, pp. 153-170.

23 Rogers, E. M. (1995) 'Diffusion of innovations', 4th edn, The Free Press, New York, NY.

24 Citrin, A. V., Sprott, D. E., Silverman, S. N. and Stem Jr., D. E. (2000) 'Adoption of internet shopping: The role of consumer innovativeness'. Industrial Management E Data Systems, Vol. 100, No. 7, pp. 294-300. 
25 Parasuraman, A. (2000) 'Technology readiness index (tri): A multiple-item scale to measure readiness to embrace new technologies', Journal of Service Research, Vol. 2, No. 4, pp. 307-320.

26 Carlson, R. E. and Wright, D. G. (1993) 'Computer anxiety and communication apprehension: Relationship and introductory college course effects', Journal of Computing Research, Vol. 9, No. 3, pp. 329338.

27 Barclay, D., Higgins, C. and Thompson, R. (1995) 'The partial least squares approach to causal modeling: Personal computer adoption and use as illustration', Technology Studies, Vol. 2, No. 2, pp. 285-309.

28 Chin, W. (1998) 'The partial least squares approach to structural equation modeling', in Marcoulides G. A. (ed.) 'Modern business research methods', Lawrence Erlabaum Associates, Mahwah, NJ.

29 Fornell, C. and Bookstein, F. (1982) 'Two structural equation models: Lisrel and pls applied to consumer exit-voice theory', Journal of Marketing Research, Vol. 19, No. 4, pp. 440-452.

30 Lohmöller, J.-B. (1989) 'Latent variable path modelling with partial least squares', Physica-Verlag, Heidelberg, Germany.

31 Wold, H. (1985) 'Partial least squares', in Kotz S. and Johnson N. L. (eds) 'Encyclopedia of statistical sciences', Wiley, New York, pp. 581-591.

32 Chin, W. (2001) 'Pls-graph user's guide version 3.0', C.T. Bauer College of Business, University of Houston, Houston, TX.

33 Fornell, C. and Larcker, D. (1981) 'Evaluating structural equation models with unobservable variables and measurement error', Journal of Marketing Research, Vol. 18, No. 3, pp. 39-50.

34 Werts, C. E., Linn, R. L. and Jöreskög, K. G. (1974) 'Intraclass reliability estimates: Testing structural assumptions', Educational and Psychological Measurement, Vol. 34, pp. 25-33.

35 Nunnally, J. C. and Bernstein, I. H. (1994) 'Psychometric theory', McGraw-Hill, New York.

36 Howell, J. M. and Aviolo, B. J. (1993)

'Transformational leadership, transactional leadership, locus of control, and support for innovation: Key predictors of consolidated-business-unit-performance', Journal of Applied Psychology, Vol. 78, No. 6, pp. 891902.

37 Efron, B. and Tibshirani, R. J. (1993) 'An introduction to the bootstrap', Chapman and Hall, New York.

38 Duxbury, L. E. and Higgins, C. A. (1991) 'Gender differences in work-family conflict', Journal of Applied Psychology, Vol. 76, No. 1, pp. 60-74.

39 Chin, W. W. (2000) 'Frequently asked questions partial least squares \& pls-graph', Home Page [Online]. retrieved 5th November, 2002: http://discnt.cba.uh.edu/chin/plsfaq.htm.

40 Teo, T. S. H. (2001) 'Demographic and motivation variables associated with internet usage activities', Internet Research: Electronic Network Applications and Policy, Vol. 11, No. 2, pp. 125-137.

41 Mathwick, C., Malhotra, N. and Rigdon, E. (2001) 'Experiential value: Conceptualization, measurement and application in the catalog and internet shopping environment', Journal of Retailing, Vol. 77, No. 1, pp. 39-56.

42 Grewal, R., Mehta, R. and Kardes, F. R. (2000) 'The role of the social-identity function of attitudes in consumer innovativeness and opinion leadership', Journal of Economic Psychology, Vol. 21, No. 3, pp. 233 252

43 Advani, R. and Choudhury, K. (2001) 'Making the most of b2c wireless', Business Strategy Review, Vol. 12, No. 2, pp. 39-49. 
Copyright of Journal of Financial Services Marketing is the property of Henry Stewart Publications and its content may not be copied or emailed to multiple sites or posted to a listserv without the copyright holder's express written permission. However, users may print, download, or email articles for individual use. 